\title{
Chemical composition and antibacterial activity of essential oil of Senecio graciliflorus
}

\author{
B.C. Joshi' ${ }^{1}$, Vinod Kumar*2, Bhuwan Chandra' ${ }^{2}$ N.D. Kandpal ${ }^{2}$ \\ ${ }^{1}$ Department of Chemistry, M.B.P.G. College, Haldwani, Nainital, Uttarakhand, India \\ ${ }^{2}$ Department of Chemistry, Kumaun University, S.S.J. Campus, Almora, Uttarakhand, India
}

\begin{abstract}
Objective: Among natural products, essential oils and their contituents represent a structurally diverse group of organic compounds with significant antibacterial activity. This study is oriented to assess the therapeutic potential of plant constituents as new antimicrobial drugs. Methods: Aerial parts of Senecio graciliflorus was steam distilled and analysed by GC and GC-MS for the volatile constituents. Essential oil was studied for their antibacterial activity against Gram-positive and Gram-negative bacteria using agar well diffusion method.

Results: The results revealed that $\alpha$-pinene and $\alpha$-thujene are the major constituents of $S$. graciliflorus oil. In vitro studies showed significant antimicrobial activity against bacterial strains.

Conclusion: This study demonstrated that the oil significantly inhibits the growth of baceria. S. graciliflorus would be another alternative for developing new pharmaceuticals for prevention bacterial diseases and provide a direction for the study of naturally derived drugs.
\end{abstract}

Keywords: Asteraceae, Senecio graciliflorus, Essential oil, $\alpha$-Pinene, Antibacterial activity.

Article Info: Received 19 Dec 2018; $\quad$ Review Completed 25 Jan 2019; $\quad$ Accepted 28 Jan 2019; Available online 15 Feb 2019

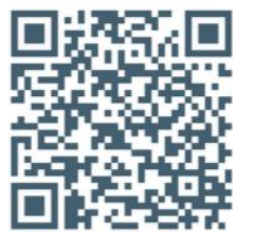

Cite this article as:

Joshi BC, Kumar V, Chandra B, Kandpal ND, Chemical composition and antibacterial activity of essential oil of Senecio graciliflorus, Journal of Drug Delivery and Therapeutics. 2019; 9(1-s):98-100 DOI: http://dx.doi.org/10.22270/jddt.v9i1-s.2265

*Address for Correspondence:

Vinod Kumar, Department of Chemistry, M.B.P.G. College, Haldwani, Nainital, Uttarakhand, India

\section{INTRODUCTION}

Essential oils are important natural products and sources of important aroma chemicals. These natural products are useful in perfumary and pharmaceutical industry. The class of terpenoids belong to natural products had gathered importance in recent years due to their biological and pharmacological activity.

The genus Senecio, which belongs to the tribe Senecioneae, is the largest and the most complex genus in the family of the Asteraceae and includes more than 1500 species of aromatic herbs and shrubby plants with a worldwide distribution ${ }^{1}$. Several of these have been extensively investigated for their secondary metabolites. A few herbaceous species of the genus are grown as ornamental plants. The leaves are alternate in arrangement and the flowers are coloured (mostly yellow, blue, purple or white). Senecio species have been used in the folk medicine for the treatment of wounds and as antiemetic, anti-inflammatory and vasodilatory preparations $^{2}$. In traditional medicine, the use of Senecio species for treatment of asthma, coughs, bronchitis, stomach ache, blood purifiers for skin eruptions, burns and wound healing have been reported ${ }^{3}$.

Volatile constituents of Senecio species mainly contain monoand sesquiterpene hydrocarbons and their oxygenated derivatives. Senecio crude extracts are known to possess various biological activities such as antimicrobial activity viz. antibacterial, antifungal, and antitubercular activities; molluscicidal and cytotoxic activities ${ }^{4}$. The aim of the present work was to determine the volatile composition and evaluation of antibacterial potential of Senecio graciliflorus form Uttarakhand Himalaya.

\section{MATERIALS AND METHODS}

\section{Plant materials}

Aerial parts of Senecio graciliflorus was collected at the flowering stage from Himalayan region of Uttarakhand at altitude range $2600-3700 \mathrm{~m}$. The plant specimen were identified from Department of Botany, D.S.B. Campus, Kumaun University, Nainital by taxonomist and a voucher specimen have been deposited in the department.

\section{Chemicals and reagents}

All chemicals and reagents used were of analytical grade. Mueller-Hinton broth (MHB) and Mueller-Hinton agar (MHA) were obtained from Hi-Media, India.

\section{Extraction of the essential oil}

Fresh aerial parts $(\sim 2 \mathrm{~kg})$ was subjected to steam distillation. The distillate obtained after steam distillation of fresh plant material was treated with n-hexane for the 
extraction of organic constituents. The distillate was further shaken with dichloromethane to ensure complete extraction of constituents. The n-hexane and dichloromethane extracts were combined and dried over anhydrous $\mathrm{Na}_{2} \mathrm{SO}_{4}$. Solvent was distilled off in a rotary vacuum evaporator to get residual oil which was stored at $\sim 4{ }^{\circ} \mathrm{C}$.

\section{GC and GC-MS analysis}

The oil samples were analyzed using a gas chromatograph (GC) (Varian vista 6000 equipped with D.B-5 non-polar fused silica capillary column $(60 \mathrm{~m} \times 0.40 \mathrm{~mm}$, film thickness: 0.25 $\mu \mathrm{m})$. The oven temperature $\left(40-250^{\circ} \mathrm{C}\right)$ was programmed at $3{ }^{\circ} \mathrm{C} / \mathrm{min}$ and retained at $250^{\circ} \mathrm{C}$ till analysis was complete. The injector and detector temperatures were $250{ }^{\circ} \mathrm{C}$ each and the injection volume $0.5 \mu \mathrm{L}$, using a $10 \%$ solution of the oil in $n$-hexane. The GC-MS was conducted on a Thermo Quest Trace GC 2000 (ThermoQuest/ Finnigan) interfaced with a Finnigan MAT Polaris Q ion trap mass spectrometer using similar operating parameters as in GC with injection volume $0.10 \mu \mathrm{L}$ and the split ratio was $1: 40$. The MS were taken at $70 \mathrm{eV}$ with a mass range of 40-450 amu. Identification of components of the essential oils was done with published data and NIST and WILEY mass spectral library data.

\section{Bacterial strains}

The in vitro antibacterial activity was evaluated against a panel of pathogenic and clinically isolated 4 bacterial strains [Pseudomonas aeruginosa (MTCC No. 424), Escherichia coli (MTCC No. 443), Staphylococcus aureus (MTCC No. 737) and Salmonell typhi (MTCC No. 531)]. The test strains were provided by the Department of Microbiology, Sushila Tewari Forest Hospital Trust, Haldwani, Nainital, Uttarakhand which were procured from the Institute of Microbial Technology, Chandigarh. Microbial technology culture collection (MTCC) numbers represent the standard strain numbers assigned to these microorganisms. The cultures of bacteria were maintained on agar slants at $4{ }^{\circ} \mathrm{C}$ throughout and used as stock cultures.

\section{Antibacterial activity evaluation}

Antimicrobial activity evaluation of the oil was done by the agar well diffusion method ${ }^{5}$. The samples were dissolved in dimethyl sulphoxide (DMSO) to prepare desired concentrations. Inoculums of the microbial strains $\left(1 \times 10^{6}\right.$ $\mathrm{CFU} / \mathrm{mL}$ ) were plated using sterile swabs into petri dishes $(90 \mathrm{~mm})$ with $20 \mathrm{~mL}$ of Mueller-Hinton agar, where $2 \mathrm{~mm}$ wells were cut and filled with $15 \mu \mathrm{L} / \mathrm{mL}$ of sample. Standard antibiotic gentamycin was used as positive control and DMSO as negative control. The petri dishes were preincubated for $3 \mathrm{~h}$ at room temperature, allowing the complete diffusion of the samples and then incubated at $37 \pm 1^{\circ} \mathrm{C}$ for $24 \mathrm{~h}$. The zones of inhibition were observed and measured in $\mathrm{mm}$.

\section{RESULT AND DISCUSSION}

The quantitative and qualitative analysis of essential oils of $S$. graciliflorus collected Kumaun region of Uttarakhand Himalaya are listed in Table 1 in the order of their elution time from an D.B-5 non-polar fused silica capillary column and their GC spectra. A total 19 compounds were identified accounting for $80.1 \%$ of the total composition of the essential oil. Oil was composed of monoterpene hydrocarbones (32.0\%), oxygenated monoterpenoides (8.6\%), sesquiterpene hydrocarbons (36.5\%) and oxygenated sesquiterpenoids (3.0\%). The essential oil of $S$. graciliflorus showed the presence of $\alpha$-Pinene (15.0\%), $\alpha$ thujene $(10.0 \%)$ followed by the $\beta$-caryophyllene $(9.7 \%)$, germacrene-D $(9.3 \%), \alpha$-ylangene $(9.9), \delta$-silenene $(7.5 \%)$ and terpinen-4-ol (4.4\%). Previous reports on the essential oil of Senecio graciliflorus showed monoterpene hydrocarbons predominated in the essential oil with $85.28 \%$ in flower, $57.53 \%$ in leaf, $67.74 \%$ in stem and $64.98 \%$ in root oil. $\alpha$-Pinene, cis-ocimene, 1,2,3-trimethylcyclohexane and $\beta$ pinene were the major constituents of the essential oil 6 . As compared to the previous reports our results revealed major differences in chemical constituents of the oil.

Table 1: Chemical composition of essential oil from Senecio graciliflorus

\begin{tabular}{|c|c|c|c|c|c|}
\hline No. & Compound & RIa & $\mathrm{RI}^{\mathrm{b}}$ & \% Composition & $\begin{array}{c}\text { Method of } \\
\text { identification }\end{array}$ \\
\hline & $\alpha$-Thujene & 930 & 932 & 10.0 & \\
\hline & $\alpha$-Pinene & 939 & 940 & 15.0 & d,e \\
\hline & $\beta$-Pinene & 979 & 981 & 2.0 & d,e \\
\hline & $\delta$-2-Carene & 1002 & 1000 & 1.7 & d,e \\
\hline & Limonene & 1029 & 1054 & 1.4 & $\mathrm{c}, \mathrm{d}, \mathrm{e}$ \\
\hline & $\beta$ - $(E)$-Ocimene & 1050 & 1070 & 1.2 & d,e \\
\hline & Terpinolene & 1088 & 1089 & 0.7 & $\mathrm{c}, \mathrm{d}, \mathrm{e}$ \\
\hline & trans-Verbenol & 1144 & 1146 & 3.2 & $\mathrm{~d}, \mathrm{e}$ \\
\hline & Verbenone & 1205 & 1206 & 1.0 & d,e \\
\hline & Terpinen-4-ol & 1177 & 1179 & 4.4 & $\mathrm{c}, \mathrm{d}, \mathrm{e}$ \\
\hline & $\alpha$-Ylangene & 1375 & 1375 & 9.9 & $\mathrm{~d}, \mathrm{e}$ \\
\hline & $\beta$-Caryophyllene & 1418 & 1421 & 9.7 & $\mathrm{c}, \mathrm{d}, \mathrm{e}$ \\
\hline & $\gamma$-Himachalene & 1482 & 1485 & 0.1 & d,e \\
\hline & Germacrene-D & 1481 & 1885 & 9.3 & $\mathrm{c}, \mathrm{d}, \mathrm{e}$ \\
\hline & $\delta$-Silenene & 1490 & 1498 & 7.5 & $\mathrm{~d}, \mathrm{e}$ \\
\hline & epi-Cubebol & 1494 & 1502 & 1.4 & d,e \\
\hline & Germacrene D-4-ol & 1575 & 1574 & 1.4 & d,e \\
\hline & Cubenol & 1646 & 1647 & 0.1 & d,e \\
\hline & $\alpha$-Eudesmol (3) & 1653 & 1652 & 0.1 & d,e \\
\hline & Total identified & & & 80.1 & \\
\hline & Total unidentified & & & 19.9 & \\
\hline & Oil yield $(\%, v / w)$ & & & 0.1 & \\
\hline
\end{tabular}


The antibacterial activity of the essential oils of $S$. graciliflorus was assessed against bacterial strains, exhibited significant antibacterial activity against all bacterial strains tested (Table 2). All the strains were tested were found to be affected by essential oil by important zone of inhibition ranged from 3.3-8.6 $\mathrm{mm}$. Based on inhibition zones $S$. graciliflorus essential oil was more active against $S$. aureus $(\mathrm{ZOI}=8.6 \mathrm{~mm})$, oil was also able to inhibit E. coli $(\mathrm{ZOI}=6.0$ $\mathrm{mm}$ ). Furthermore, it was found that all the strains was registsance against tested oil, very registive strain especially $P$. aeruginosa $(\mathrm{ZOI}=3.3 \mathrm{~mm})$ followed by $S$. typh $>$ E. coli and S. aureus.

Table 2: Antibacterial activity of essential oil of Senecio graciliflorus

\begin{tabular}{|c|c|c|}
\hline \multirow{2}{*}{ Bacterial strains } & \multicolumn{2}{|c|}{ Daimeter of Inhibition Zone (mean \pm SD) $\mathrm{mm}^{\mathrm{a}}$} \\
\hline & Essential oil & Reference antibiotic \\
\hline S. typhi & $4.2 \pm 0.1$ & $18.4 \pm 0.2$ \\
\hline E. coli & $6.0 \pm 0.2$ & $24.3 \pm 0.1$ \\
\hline S. aureus & $8.6 \pm 0.3$ & $21.0 \pm 0.2$ \\
\hline P. aeruginosa & $3.3 \pm 0.2$ & $20.6 \pm 0.2$ \\
\hline
\end{tabular}

aInhibition zone diameter includes well diameter

Essential oils (EOs) were extensively tested against a broad spectrum of bacteria, yeasts, and fungi. The interaction between EOs and microbes which ultimately induces the antimicrobial activity is not well understood. Studies on the mode of action of EOs have been reported on bacterial and fungal targets involved in cytoplasmatic and cell wall metabolism 7,8 . Essential oils are complex mixture of numerous molecules, and one might wonder if their biological effects are the results of a synergism of all molecules or reflect only those of the main molecules present at highest levels. Generally, the major components are found to reflect quite well the biophysical and biological features of the EOs from which they were isolated ${ }^{9}$ the amplitude of their effect being just dependent on their concentration when they were tested alone or comprised in EOs. Thus, synergistic functions of the various molecules contained in an EOs as compared to the action of one or two main components of the oil. However, it is possible that the activity of the main components is modulated by other minor molecules ${ }^{10}$.

Previous study showed that the monoterpenoid rich essential oil of $S$. graciliflorus DC exhibits fair amount of cytotoxic and antioxidant activity. The highest content of monoterpene hydrocarbons was found in flower oil $(85.28 \%)$ and $\alpha$-pinene as the most abundant constituent $(36.36 \%)$ in root oil. The pharmacological effect that this oil depicts is believed to be the outcome of the synergistic effect of the major constituents 6 . As comparision with the previous data oil of Senecio graciliflorus collecteed from Kumaun region of Uttarakhand Himalaya is dominate in presence of monoterpene hydrocarbons ( $\alpha$-Thujene and $\alpha$-pinene) showed the significant antimicrobial activity due to the major constituents as well as synergetic effect of other minor bioactive constituents present in the oil.

\section{CONCLUSION}

Aromatic and medicinal plants are known to produce certain bioactive molecules which react with other organisms in the environment, inhibiting bacterial or fungal growth. The substances that can inhibit pathogens and have little toxicity to host cells are considered for developing new antimicrobial drugs. This study thus reflects that $S$. graciliflorus could be considered as a new potential natural source of monoterpene rich oil that exhibits potent antibacterial effect.

\section{ACKNOWLEDGEMENTS}

Authors would like to thank Department of Chemistry, Kumaun University, for providing necessary lab facilities, Department of Botany Kumaun University for plant identification and Department of Microbiology, Sushila Tewari Forest Hospital Trust, Haldwani for antimicrobial activity.

\section{REFERENCES}

1. Nordenstam B., Senecioneae and Liabeae-systematic review. In: The Biology and Chemistry of the Compositae, Heywood V.H., Harborne J.B., Turner B.L., Eds. Academic Press: London, UK, 2, 1977; pp. 799-830.

2. Conforti F, Loizzo M.R., Statti G.A., Houghton P.J., Menichini F., Biological properties of different extracts of two Senecio species. Int. J. Food Scie. Nutri. 2006; 57 (1/2):1-8.

3. Uzun E., Sariyar G., Adsersen A., Karakoc B., Otuk G., Oktayoglu E., Pirildar S., Traditional medicine in Sakarya Province (Turkey) and antimicrobial activities of selected species. J. Ethnopharmacol. 2004; 95:287-296.

4. Loizzo M.R., Tundis R., Statti G.A., Menichini F., Jacaranone: A cytotoxic constituent from Senecio ambiguus subsp. ambiguus (Biv.) DC. against renal adenocarcinoma a CHN and prostate carcinoma LNCaP cells. Arch. Pharm. Res. 2007; 30:701-707.

5. Clinical and Laboratory Standards Institute. Performance Standards for Antimicrobial Disk Susceptibility Tests, 10th Ed. Approved standard. Document M02-A10, CLSI, Wayne, Pa. 2009.

6. Lone S. H., Bhat K. A., Bhat H. M., Majeed R., Anand R., Hamid A. and Khuroo M.A. Essential oil composition of Senecio graciliflorus DC: Comparative analysis of different parts and evaluation of antioxidant and cytotoxic activities. Phytomedicine. 2014; 21:919-925.

7. Hammer K.A., Carson C.F., Riley T.V., Antifungal effects of Melaleuca alternifolia (tea tree) oil and its components on Candida albicans, Candida glabrate and Saccharomyces cerevisiae. J. Antimicrob. Chemother. 2004; 12:1-5.

8. Takaisi-Kikuni N.B., Kriiger D., Gnann W., Wecke J., Microcalorimetric and electron microscopic investigation on the effects of essential oil from Cymbopogon densiflorus on Staphylococcus aureus. Microbios. 1996; 88:55-62.

9. Ipek E., Zeytinoglu H., Okay S., Tuylu B.A., Kurkcuoglu M., Husnu Can Baser K., Genotoxicity and antigenotoxicity of Origanum oil and carvacrol evaluated by Ames salmonella/ microsomal test. Food Chem. 2005; 93:551-556.

10. Hoet S., Stevigny C., Herent M.F., Quetin-Leclercq, J., Antitrypanosomal compounds from leaf essential oil of Strychnos spinosa. Planta Med. 2006; 72:480-482. 